\title{
A reconstrução da viabilidade econômico-financeiro da saúde a partir do resgate do mutualismo
}

\author{
João de Boaventura Branco MATOS ${ }^{(1)}$ \\ George Edwards Machado KORNIS ${ }^{(1)}$ \\ (1)Instituto de Medicina Social, Universidade do Estado do Rio de Janeiro - UERJ, Rio de Janeiro, \\ RJ, Brasil.
}

Recebido: 28 jan 2019 Aceito: 10 fev 2019

Autor de correspondência: jmatos@espm.br

Conflito de interesses: Os autores declaram não haver nenhum interesse profissional ou pessoal que possa gerar conflito de interesses em relação a este manuscrito.

\section{Resumo}

A Declaração de Alma-Ata de 1978 e posteriormente a Constituição brasileira de 1988 são resultantes de um contexto político e econômico no qual se imaginava uma concepção mais abrangente e humanista no campo da saúde. A saúde era vista como um direito humano fundamental, a partir do qual seriam mitigadas as desigualdades políticas e econômicas e afirmada a cidadania. Tal mudança, entretanto, estaria a exigir ação política efetiva por parte dos atores sociais. Caso contrário, tímidos e insuficientes seriam os avanços no enfrentamento ao poder do mercado e da perda de legitimidade dos Estados nacionais. Passadas quatro décadas desde a conferência e três décadas da constituição cidadã, o que se viu foi o encerramento da chamada era de ouro do capitalismo mundial e uma franca desagregação da ordem internacional vigente. Paradoxalmente, o desenvolvimento tardio do Estado do bem-estar no Brasil não permitiu que fossem construídos os diques de contenção necessários ao enfretamento da crise. Diante da impossibilidade de afirmação de uma hegemonia dos sistemas públicos de saúde, os esforços passaram a se concentrar na busca pela redução das fricções provenientes do choque de visões e objetivos provenientes das dimensões público e privada. Nessa esteira, os países passaram a dotar um tipo uma atenção primária seletiva e mais barata, com foco nos mais pobres, deixando de lado os objetivos de universalidade. Todavia, estas ações ficaram longe de ser alcançadas especialmente a partir do aprofundamento dos efeitos da crise internacional de 2008 e do ressurgimento de coalizões governistas, ficaram ainda mais distantes do pensamento de saúde coletiva, que é o de atrelar a saúde ao papel político do Estado. Objetivo: especialmente na América Latina, estamos diante de um quadro de sucessivas crises de financiamento dos Estados nacionais, que têm levado ao aprofundamento do fosso que separa o mundo atual dos fundamentos do pensamento de saúde coletiva. Diante deste flagrante quadro de deterioração e primados pela necessidade de reafirmar os princípios da saúde coletiva em ambiente político e econômico adverso. Nesse contexto, o objetivo principal passa a ser o desenvolvimento de uma estratégia, ainda que defensiva ou transitória, para o estabelecimento de uma agenda mínima de busca pela sustentabilidade econômico-financeira dos sistemas de saúde. O grande desafio que o momento atual nos coloca é exatamente buscar a solvência em 
ambiente de crescimento da insolvência, buscar a igualdade em ambiente de aprofundamento das desigualdades e buscar um olhar solidário e fraternal em ambiente radicalizado e individualista. A busca do resgate do mutualismo no campo da Saúde Suplementar, e por extensão no campo da saúde como um todo, este trabalho utiliza o conceito de bem comum presente em Hardt e Negri, com o objetivo de prospectar interesses comuns que possibilitem restabelecimento e consolidação do mutualismo na Saúde Suplementar. O mutualismo é princípio fundamental que constitui a base de toda relação securitária, já que se trata de um movimento associativo de solidariedade social privada, que, portanto, exige a prática de ações solidárias. Essas ações, entretanto, seriam inviáveis a partir da ação individualizada dos beneficiários ou mesmo das operadoras de plano de saúde. Assim, com o fito de assegurar a unicidade do sistema como requisito fundamental ao mutualismo e, por extensão à sobrevivência do setor, a Agência Nacional de Saúde Suplementar - ANS surge como a única entidade capaz de promover este movimento associativo. Ocorre, entretanto, que a crise pela qual estamos passando se espraia para além da conjuntura econômica, atingindo também as instituições públicas e privadas. No setor da saúde suplementar, sintomas dessa crise vão para além da redução do número de beneficiários nos últimos três anos. Buscando a sobrevivência, as operadoras de planos de saúde passaram a investir numa lógica de oferta de contratos de curto prazo para pequenos grupos, promovendo assim a seleção de risco no setor. Se levado ao paroxismo, esse movimento pode chegar num tratamento caso a caso, destruindo completamente o movimento associativo, que é precisamente a base do mutualismo e da existência do setor. Metodologia: é sabido que a busca pelo interesse comum é examinada em um contexto dinâmico e em um espaço estruturado de posições, nem sempre harmoniosas, iguais ou convergentes. Apesar das divergências, é possível identificar e extrair alguns elementos comuns que contribuem para o resgate da ideia de mutualismo. A partir da identificação e sistematização desses elementos comuns, foi possível estabelecer um conjunto de ações que, uma vez desenvolvidas em conjunto, podem contribuir para a redução de custos no setor e, consequentemente, para a viabilidade futura do sistema de saúde. O método para identificação desses elementos se baseou numa análise empírica e qualitativa dos principais fatores geradores ou amplificadores de custos no setor. Importante destacar que a redução de custos atende aos interesses comuns seja o dos segurados ou dos seguradores. Resultados: foram elencadas algumas ações regulatórias significativas que, uma vez adotadas pela ANS, poderão contribuir de forma significativa para o resgate do mutualismo e, por extensão, para a redução dos custos da saúde e melhoria do equilíbrio econômico-financeiro do setor. Conclusões: não obstante as buscas por reavivar os debates sobre a determinação social da saúde a partir de uma agenda mais participativa, esses esforços ficaram distantes de ser alcançados. Na esfera mundial, isso pode ser atribuído ao processo de desmantelamento da ordem mundial manifesta a partir das dimensões política e econômica. Mais recentemente, com o aprofundamento 
dos efeitos da crise internacional de 2008 e com o ressurgimento de coalizões governistas menos comprometidas com a determinação social da saúde, os objetivos da Saúde Coletiva têm se tornado ainda mais distantes. No caso brasileiro, além da crise de financiamento do Sistema Público e num contexto de radical transição demográfica, vem se observando na esfera privada um comportamento defensivo por parte dos agentes econômicos, levando à deterioração do mutualismo. Este trabalho procurou contribuir para ampliar o debate em torno de uma agenda ainda vigente, que coloca a saúde como um direito humano fundamental. Para tanto, propõe o desenvolvimento de uma agenda mínima que contribua para o resgate do mutualismo e da sustentabilidade econômico-financeira da Saúde Suplementar e por extensão da Saúde como um todo.

Descritores: Saúde Suplementar; Regulação e Fiscalização em Saúde; Parcerias Público-Privadas. 